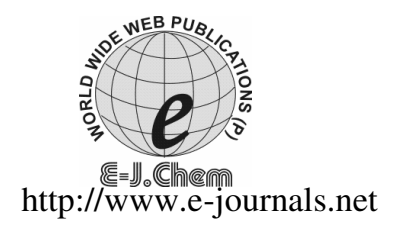

\title{
Electrochemical Reduction Behaviour of Zileuton at a Dropping Mercury Electrode by Polarography
}

\author{
N. Y. SREEDHAR*, M. SANKARA NAYAK, K. SRINIVASA PRASAD, \\ P. R. PRASAD and C. NAGESWAR REDDY \\ Electroanalytical Lab, Department of Chemistry, \\ Sri Venkateswara University, Tirupati, A.P, India. \\ sankarmude@yahoo.co.in
}

Received 27 March 2009; Revised 3 June 2009; Accepted 1 August 2009

\begin{abstract}
Electrochemical behaviour of anticancer drug zileuton was investigated by direct current polarography (DCP) and differential pulse polarography using a dropping mercury electrode (DME) as working electrode and $\mathrm{Ag} / \mathrm{AgCl}$ reference electrode in universal buffer of $\mathrm{pH}$ range from 2.0 to 12.0. The drug was extracted from the dosage forms in dimethyl formamide (DMF). Kinetic parameters such as diffusion co-efficient (D) and heterogeneous forward rate constants $\left(\mathrm{k}^{0} \mathrm{f}, \mathrm{h}\right)$ are evaluated and reported. The differential pulse polarographic method has been developed for the determination of this drug in pharmaceutical formulations.
\end{abstract}

Keywords: Zileuton, Polarography, Dropping Mercury Electrode (DME).

\section{Introduction}

Zyflo (Zileuton; $N$-(1-benzo[b]thien- 2-ylethyl)- $N$-hydroxyurea) (Figure 1), a substituted hydroxamic acid, is a potent and selective 5-lipoxygenase inhibitor that has been approved for the prevention ${ }^{1}$. The formulation from the manufacturer is a racemic mixture of $\mathrm{R}(+)$ and $\mathrm{S}(-)$ enantiomers. Zileuton is well absorbed and the majority of the dose $(\sim 75 \%)$ is recovered in the urine of the healthy volunteers as the $N$-hydroxy glucuronides of both the $\mathrm{R}(+)$ and $\mathrm{S}(-)$ enantiomers ${ }^{2}$.

Zileuton is metabolized in the presence of $\mathrm{NADPH}^{3}$ as anticipated, zileuton has a minimal effect on the pharmacokinetics of drugs that are metabolized by CYP2C9 (e.g., (S) warfarin, phenytoin, and naproxen) and CYP3A4 (e.g.,terfenadine $)^{4}$. In contrast, zileuton decreases the oral clearance of (R)-warfarin, propranolol, antipyrine and theophylline, which indicates that, it is a clinically relevant inhibitor of CYP1A2 $2^{5}$. Zileution was a weak inhibitor of CYP1A $2^{6}$. 


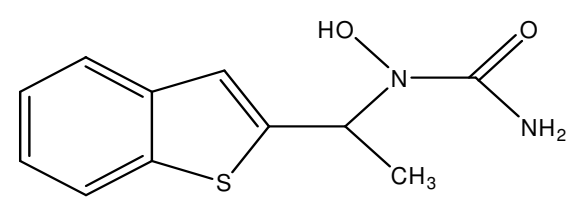

Figure 1. Structure of zileuton (zyflo).

It has several clinically important drug interactions, such as inhibiting warfarin and theophylline metabolism ${ }^{7}$. Zileuton ${ }^{8}$ and zyflamend significantly reduced infiltration of inflammatory cells, incidence of hyperplasia ${ }^{9}$.

A specific and sensitive HPLC procedure for the quantitative determination of the effect of zileuton on LPS-induced suppression of LT synthesis was similar to that of monomethyl$L$ - arginine. Zileuton had no effect on inducible nitric oxide syntheses induction ${ }^{10}$. The extraction recovery of zileuton, as determined by HPLC assay was $77.9 \pm 1.7 \%$ and recovery of the metabolite was $85.8 \pm 0.7 \%{ }^{11}$. The study suggests that zyflamend might prevent oral carcinogenesis at the post initiation stage ${ }^{12}$.

The reports on the electrochemical reduction behavior of zileuton are rather scanty. Therefore, in the present investigation the studies of electrode process associated with zileuton are treated systematically and its behavior at mercury drop electrode was also discussed. The present paper was aimed to optimize the analytical procedure for the determination of zileuton in pharmaceutical formulation.

\section{Experimental}

The chemicals used were of analytical grade. Stock solution $\left(1.0 \times 10^{-3} \mathrm{M}\right)$ was prepared by dissolving zileuton in dimethyl formamide. All dilute solutions were freshly prepared daily from the stock solution. Universal buffer solution ranging from $\mathrm{pH} 2.0$ to 12.0 were prepared using $0.2 \mathrm{M}$ boric acid, $0.01 \mathrm{M}$ citric acid and $0.1 \mathrm{M}$ tri sodium orthophosphate.

\section{Instrumentation}

Polarographic analyser model CL-362 supplied from an Elico Ltd, Hyderabad with EPSON LX $-300^{+}$recorder was used for polarographic measurements. A dropping mercury electrode was used as the working electrode, saturated calomel electrode as reference electrode and platinum wire was used as auxiliary electrode. The $\mathrm{pH}$ measurements were carried out with a $\mathrm{pH}$ meter supplied by Hanna instruments (Italy). An electrochemical experiment was performed in an undivided three electrode, all with a $10 \mathrm{~mL}$ volume of solution containing the depolarizer. All the solutions were degassed prior to analysis by bubbling purified nitrogen gas through the cell for $10 \mathrm{~min}$. A detailed description of the instrumentation and experimental conditions has been reported earlies ${ }^{13}$. All the experiments were performed at $25 \pm 1{ }^{0} \mathrm{C}$.

\section{Recommended analytical procedure}

Differential pulse polarography was employed for the developing analytical procedures for the estimation of the title compound using both standard addition and calibration methods. A standard solution of zileuton $\left(5.0 \times 10^{-4} \mathrm{M}\right)$ was prepared in dimethylformide. $1.0 \mathrm{~mL}$ of standard solution was transferred and made up with $9.0 \mathrm{~mL}$ of supporting electrolyte, then deoxygenated with nitrogen gas for $10 \mathrm{~min}$. After obtaining the polarogram, a small increment $(0.2 \mathrm{~mL})$ of the standard solution of zileuton was added to the cell and deaerated for $1 \mathrm{~min}$ and a polarogram was again recorded under similar conditions. In the same manner, 
10 polarograms were recorded for 10 standard additions. The optimum condition for the determination of zileuton at $\mathrm{pH} 4.0$ were found to be a drop time $2 \mathrm{sec}$, a pulse amplitude $50 \mathrm{mV}$ and an applied potential of $-0.28 \mathrm{~V} v \mathrm{~s}$. saturated calomel electrode.

\section{Analysis of formulations}

The required quantities of formulation corresponding to a $1.0 \times 10^{-3} \mathrm{M}$ stock solution was accurately measured and transferred into a $100 \mathrm{~mL}$ volumetric flask containing $50 \mathrm{~mL}$ DMF. A solution of approximately $5.0 \times 10^{-4} \mathrm{M}$ was prepared by dilution of this stock solution with universal buffer. Assay results for zileuton in formulation at $\mathrm{pH} 4.0$ were given in Table 2 . Recovery of zileuton ranging from 89.00 to $99.94 \%$ obtained with the proposed differential pulse polarographic method was simple, rapid, reliable and sensitive.

\section{Results and Discussion}

Zileuton exhibits only one polarographic peak/wave throughout $\mathrm{pH}$ range 2.0-12.0. This peak/wave was due to the reduction of carbonyl double bond in a two electron process. Typical polarogram were given in Figures $2 \& 3$. The diffusion controlled nature of the electrode process evidenced from the linear plots of $\mathrm{i}_{\mathrm{d}} v s . \mathrm{h}^{1 / 2}$ and $\mathrm{i}_{\mathrm{m}} v s . \mathrm{t}^{2 / 3}$ that passes through the origin indicating the absence of adsorption complication ${ }^{14}$.

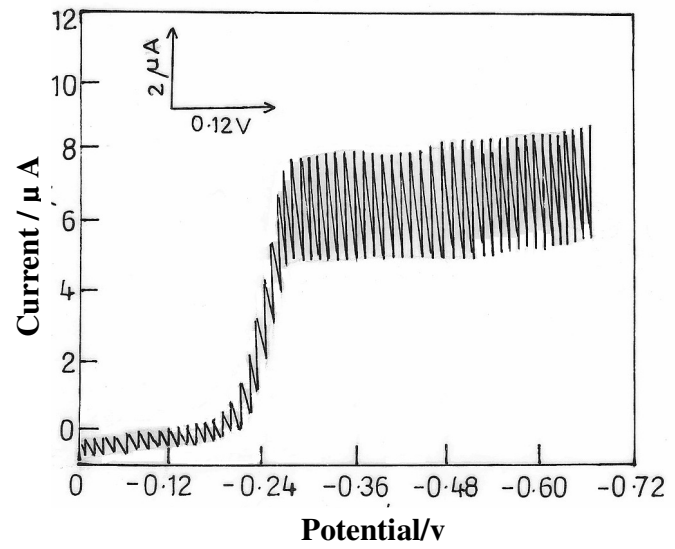

Figure 2. Typical D.C. polarogram of zileuton at $\mathrm{pH} 4.0$, Concentration $=0.5 \mathrm{mM}$, Drop time $=2$ sec.

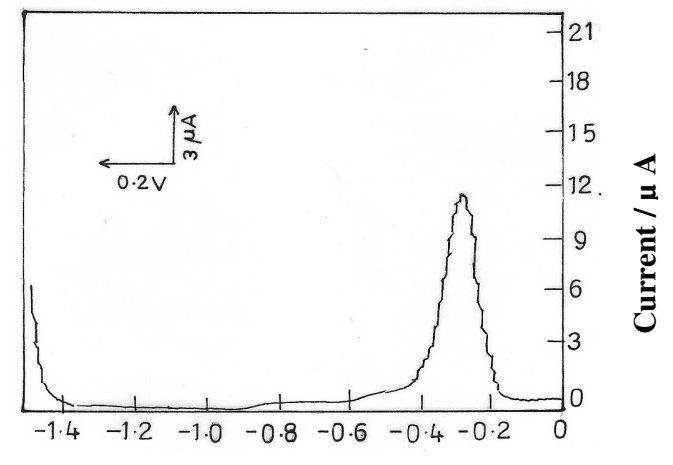

Potential/v

Figure 3. Typical differential pulse polarogram of zileuton at $\mathrm{pH} 4.0$, Concentration $=0.5 \mathrm{mM}$, Drop time $=2 \mathrm{sec}$. 
Conventional $\log$-plot analysis, variations of $E_{1 / 2}$ and $E_{m}$ (where $E_{m}$ in the potential at maximum current in differential pulse polarography) values towards more negative potentials upon increasing the concentration of zileuton ${ }^{15}$. The variation of $E_{1 / 2}$ and $E_{m}$ values forward more negative potentials on increasing the concentration of the depolarizers $^{16}$.

The various kinetic parameters of the two $\mathrm{e}^{-}$process, such as diffusion coefficient and heterogeneous forward rate constant values evaluated from the D.C. Polarography and differential pulse polarography were given respectively in Table $1 \& 2$. Under similar experimental conditions, diffusion coefficient values for zileuton in all the techniques employed were found to be of the same order. As expected a general decrease in diffusion coefficient values were noticed with increase in molecular weight of species under investigation.

Table 1. Typical D.C. polarographic data of zileuton, Concentration: $0.5 \mathrm{mM}$, Drop time: $2 \mathrm{sec}$.

\begin{tabular}{|c|c|c|c|c|c|}
\hline $\begin{array}{c}\mathrm{pH} \text { of the supporting } \\
\text { electrolyte }\end{array}$ & $\frac{-E_{1 / 2}}{V}$ & $\frac{\underline{\mathrm{i}}_{\mathrm{d}}}{\mu \mathrm{A}}$ & $\alpha_{\mathrm{na}}$ & $\frac{\mathrm{D} \times 10^{5}}{\mathrm{~cm}^{2} \mathrm{~s}^{-1}}$ & $\frac{\mathrm{K}_{\mathrm{f}, \mathrm{h}}^{0}}{\mathrm{cms}^{-1}}$ \\
\hline 2.0 & 0.10 & 7.85 & 0.98 & 2.49 & $6.81 \times 10^{-4}$ \\
\hline 4.0 & 0.24 & 7.75 & 0.95 & 2.32 & $1.20 \times 10^{-5}$ \\
\hline 6.0 & 0.29 & 7.20 & 0.95 & 2.19 & $4.77 \times 10^{-6}$ \\
\hline 8.0 & 0.35 & 7.05 & 0.87 & 2.08 & $8.54 \times 10^{-7}$ \\
\hline 10.0 & 0.42 & 6.80 & 0.83 & 2.01 & $1.35 \times 10^{-9}$ \\
\hline 12.0 & 0.53 & 6.40 & 0.79 & 1.98 & $5.43 \times 10^{-10}$ \\
\hline
\end{tabular}

Table 2. Typical differential pulse polarographic data of zileuton, Concentration: $0.5 \mathrm{mM}$, drop time: 2 sec.

\begin{tabular}{|c|c|c|c|c|c|}
\hline $\begin{array}{c}\mathrm{pH} \text { of the supporting } \\
\text { electrolyte }\end{array}$ & $\frac{-E_{m}}{V}$ & $\underline{\underline{i_{m}}}$ & $\alpha_{\mathrm{na}}$ & $\frac{\mathrm{D} \times 10^{5}}{\mathrm{~cm}^{2} \mathrm{~s}^{-1}}$ & $\frac{\mathrm{K}_{\mathrm{f}, \mathrm{h}}^{0}}{\mathrm{cms}^{-1}}$ \\
\hline 2.0 & 0.08 & 11.95 & 0.87 & 2.38 & $7.44 \times 10^{-4}$ \\
\hline 4.0 & 0.23 & 11.60 & 0.85 & 2.26 & $6.98 \times 10^{-6}$ \\
\hline 6.0 & 0.29 & 11.25 & 0.81 & 2.07 & $5.01 \times 10^{-7}$ \\
\hline 8.0 & 0.36 & 11.05 & 0.80 & 1.97 & $1.37 \times 10^{-7}$ \\
\hline 10.0 & 0.43 & 10.85 & 0.72 & 1.92 & $2.89 \times 10^{-9}$ \\
\hline 12.0 & 0.52 & 10.70 & 0.70 & 1.83 & $8.65 \times 10^{-10}$ \\
\hline
\end{tabular}

Table 3. Assay of zileuton by DPP in pharmaceutical formulations. Pulse amplitude: $50 \mathrm{mV}$, Drop time: $2 \mathrm{sec}$.

\begin{tabular}{ccccc}
\hline $\begin{array}{c}\mathrm{pH} \text { of the supporting } \\
\text { electrolyte }\end{array}$ & $\begin{array}{c}\text { Labeled amount, } \\
\mathrm{mg}\end{array}$ & $\begin{array}{c}\text { Amount found, } \\
\mathrm{mg}\end{array}$ & $\begin{array}{c}\text { Recovery, } \\
\%\end{array}$ & $\begin{array}{c}\text { Standard } \\
\text { deviation }\end{array}$ \\
\hline 2.0 & 200 & 180.00 & 90.00 & 0.022 \\
4.0 & 200 & 199.88 & 99.94 & 0.011 \\
6.0 & 200 & 192.00 & 96.00 & 0.018 \\
8.0 & 200 & 178.00 & 89.00 & 0.024 \\
\hline
\end{tabular}

The forward rate constant $\left(\mathrm{K}_{\mathrm{fh}}^{0}\right)$ values for the compound studied was found to decrease with increase in $\mathrm{pH}$. This trend shows that the electrode process becomes more and more irreversible with increase in $\mathrm{pH}$ of the solution; rate constant values are observed to be high in acidic media in general in zileuton indicating that the rate of the reaction was fast in this media because of the protonation. Based as the results obtained, the electrochemical reduction mechanism of zileuton can be proposed as in Scheme 1. 


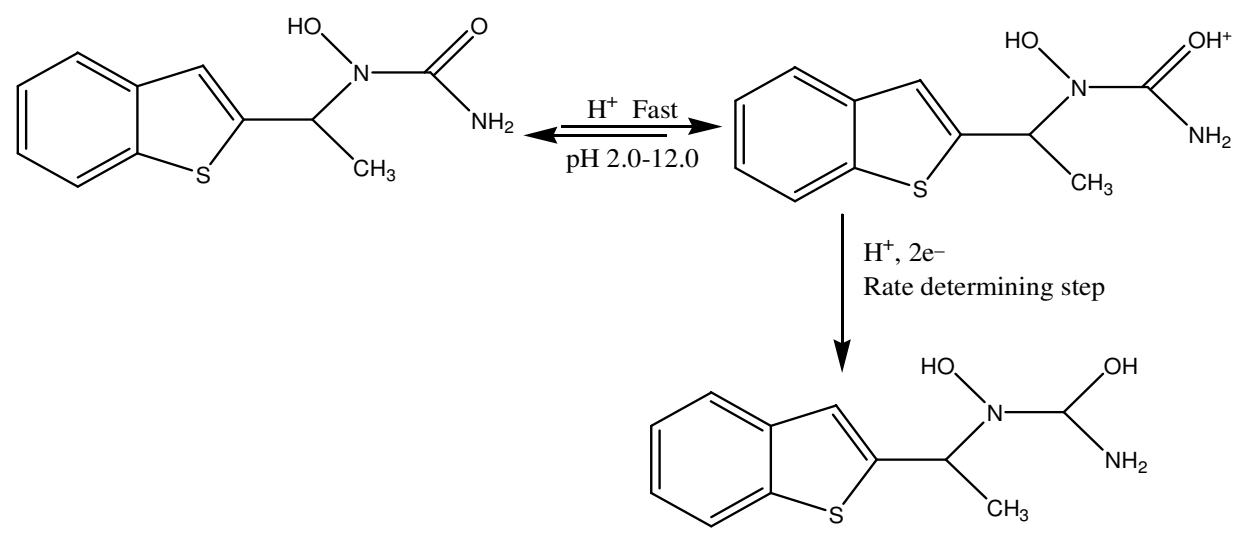

\section{Conclusion}

Scheme 1. Electrochemical reduction of zileuton.

The proposed method was experimentally convenient and sensitive for the determination of zileuton using differential pulse polarography on DME. This method was used for the determination of zileuton in pharmaceutical formulations, gives a good standard deviation values and time consume less and inexpensive. The analytical performances obtained in the present work for this substance are very better than previous methods.

\section{References}

1. Isreal E, Dermarkarian R, Rosenberg M, Sperling R, Taylor G, Rubin P and Drazen J M, N Engl J Med., 1990, 323, 1740.

2. Wong S L, Awni W M, Cavanaugh J H, El-Shourbagy T, Locke C S and Dube L M, Clin Pharmacokinet., 1995, 29, 9.

3. Machinist J M, Kukulka M J and Bopp B A, Clin Pharmacokinet, 1995, 29, 34.

4. Awni W M, Braekman R A, Cavanaugh J H, Locke C S, Linnen P J, Granneman G R and Dube L M, Clin Pharmacokinet., 1995b, 29,112.

5. Granneman G R, Braeckman R A, Locke C S, Cavanaugh J H, Dube L M and Awni W M, Clin Pharmacokinet, 1995, 29, 77.

6. Lu P, Schrag M L, Slaughter D E, Raab C E, Shou M, Rodrigues A D, Drug Metabolism and Disposition, 2003, 31(11), 1352.

7. Cafcit (caffeine citrate) package insert. Evansville, IN: Mead Johnson \& Company; 2003.

8. Thomas S B and Albazis J, J liq Chrom., 1996, 19(6), 977.

9. Yang P, Sun Z I, Chan D, Cartwright C A, Vijeswarapu M, Jibin D, Xiaoxin C, Robert A N, Carcinogenesis, 2008. 29(11), 2182.

10. Michael J Coffey, Susan M Phare and Marc Peters-Golden, J Pharmacol Exp Ther., 2001, 299(1), 198.

11. Granneman G R, Braeckman R A, Erdman K A, Clin pharmacokinet., 1995, 29(2), 1.

12. Peiying Y, Zheng S, Diana C, Carrie A, Cartwright, Mary V, Jibin D, Xiaoxin C and Robert A N, Carcinogenesis, 2008, 29(11), 2182.

13. Sreedhar N Y, Reddy P R K and Jayarama Reddy S, Bull Electrochem., 1997, 13(1), 88.

14. Meiter L, Polarographic Techniques, inter science publications, New York.1965, 248.

15. Schwade K, Advance in polarography, Gammen press Oxford, 1962, 1.

16. Gomez Nicto M A, Lugue M D, Castro D and Vakaral M, Electrochimca Acta, 1982, 27, 325 . 


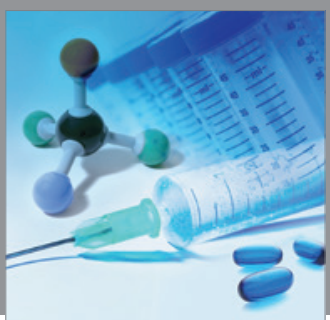

International Journal of

Medicinal Chemistry

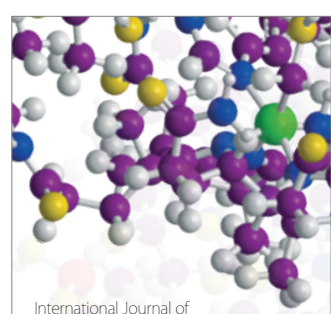

Carbohydrate Chemistry

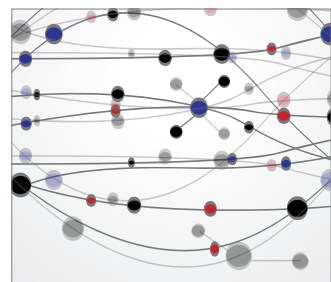

The Scientific World Journal
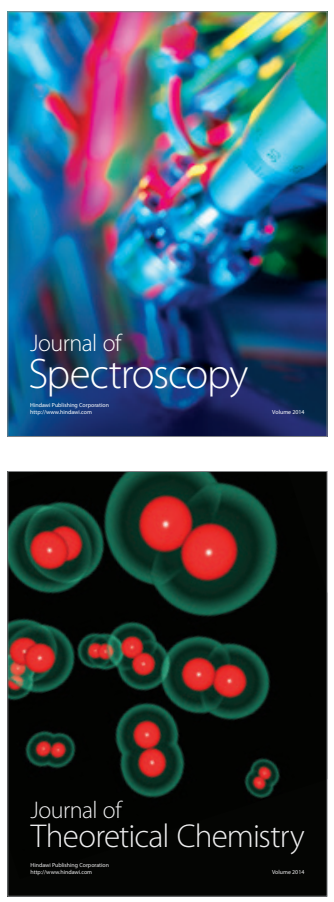
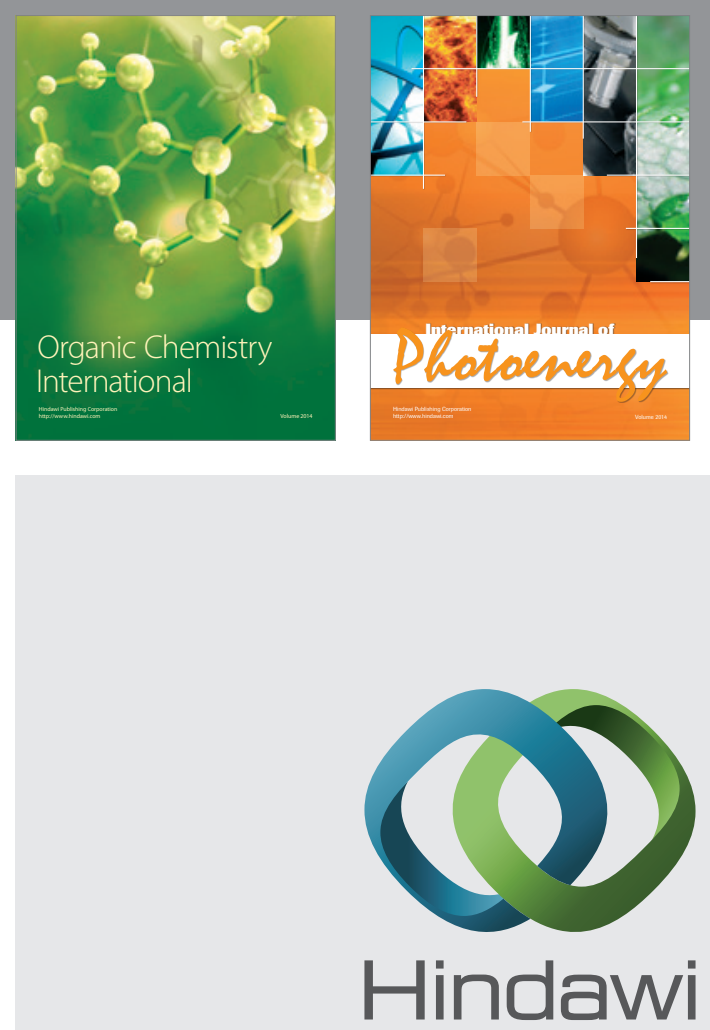

Submit your manuscripts at

http://www.hindawi.com
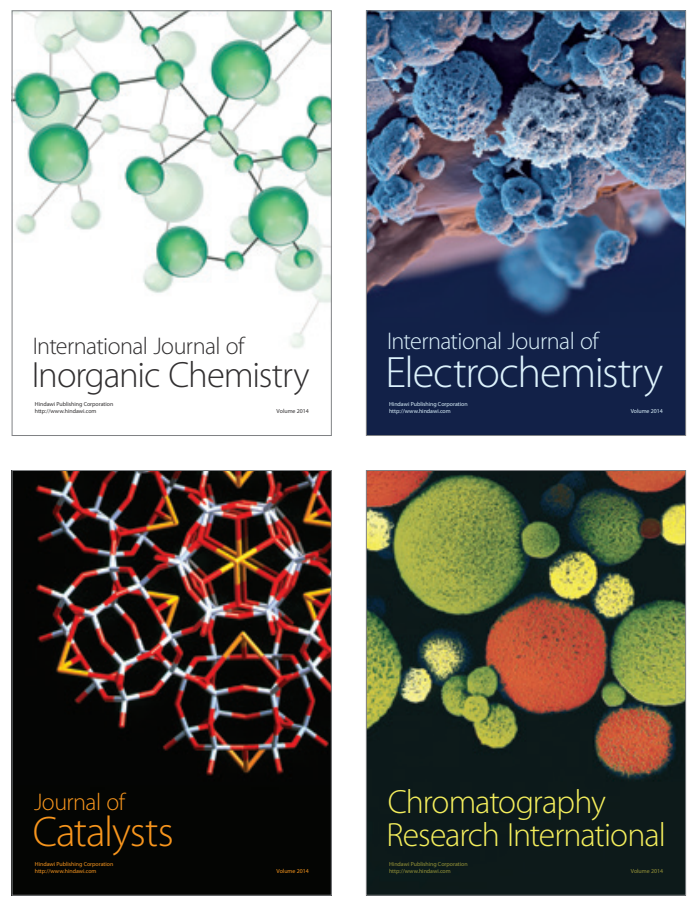
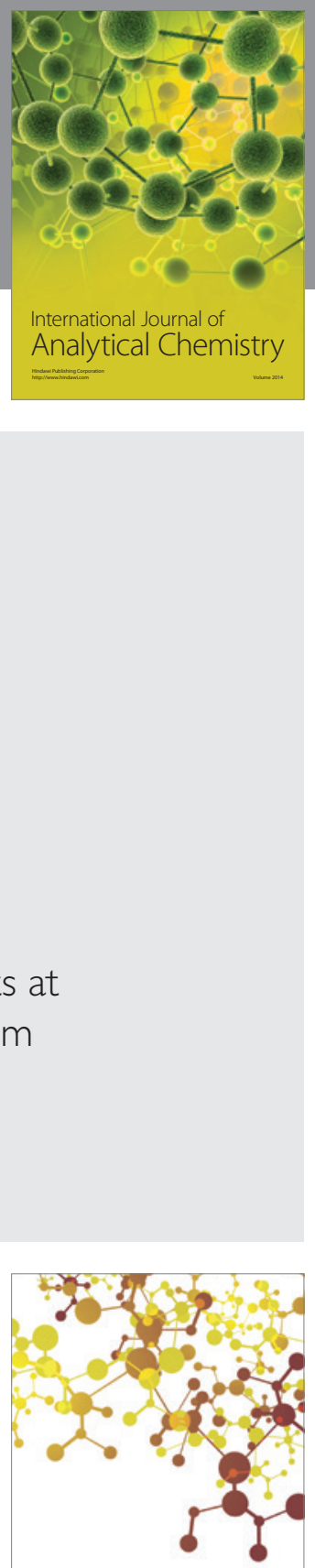

Journal of

Applied Chemistry
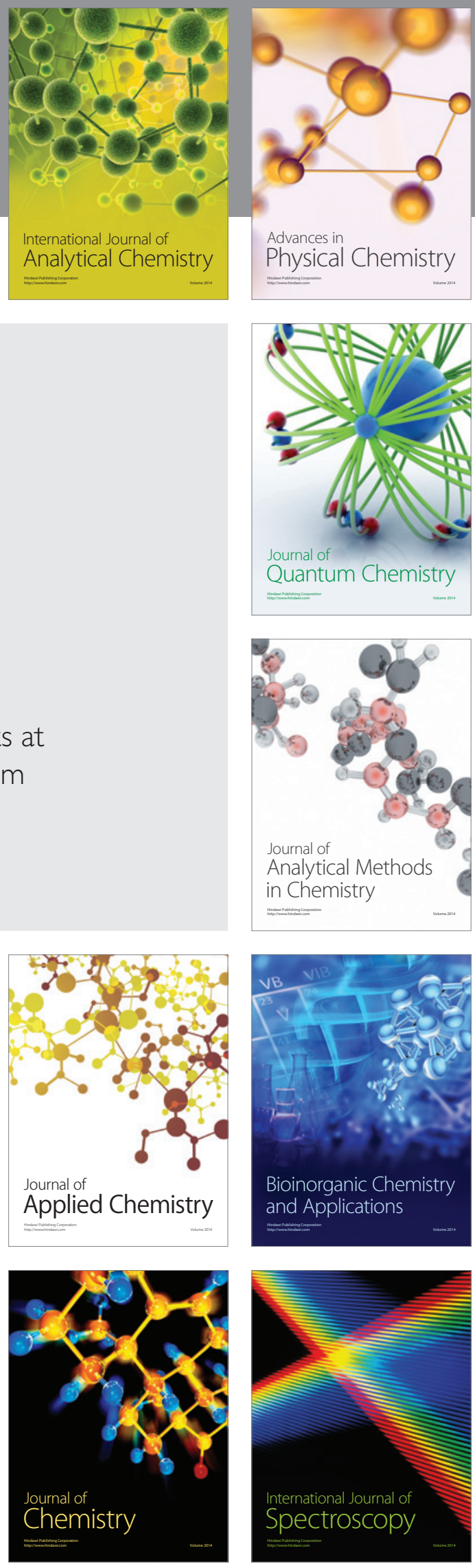